\title{
TINDAK TUTUR DAN FUNGSI TUTURAN EKSPRESIF DALAM ACARA RUMAH PERUBAHAN RHENALD KASALI
}

\author{
Cintya Nurika Irma \\ Jurusan Pendidikan Bahasa dan Sastra Indonesia, Universitas Peradaban \\ Email: cintya_nurikairma@yahoo.co.id
}

\begin{abstract}
Abstrak
Penelitian yang berjudul "Tindak Tutur dan Fungsi Tuturan Ekspresif dalam Acara Rumah Perubahan Rhenald Kasali" ini bertujuan untuk mendeskripsikan penggunaan tindak tutur yang digunakan penutur kepada lawan tutur dalam acara Rumah Perubahan Rhenald Kasali berupa tindak tutur lokusi, ilokusi, perlokusi, dan tuturan ekspresif yang berfungsi untuk mengucapkan selamat, ucapan terima kasih, mengkritik, mengeluh, heran, memuji, serta meminta maaf. Metode yang digunakan dalam penelitian ini adalah metode deskriptif kualitatif dengan teknik simak, rekam, dan catat. Hasil penelitian ditemukan adalah 10 tuturan dan tindak tutur ekspresif ditemukan 11 tuturan. Tuturan tersebut terdiri dari 3 tuturan lokusi, 2 tuturan ilokusi, 5 tuturan perlokusi, 2 tuturan ekspresif ucapan selamat, 2 tuturan ekspresif ucapan terima kasih, 1 tuturan ekspresif mengkritik, 1 tuturan ekspresif mengeluh, 2 tuturan ekspresif heran, 2 tuturan ekspresif memuji, dan 1 tuturan ekspresif meminta maaf.
\end{abstract}

Kata kunci: tindak tutur, fungsi tuturan ekspresif

\begin{abstract}
The research, entitled "Speech Act and Function of Expressives in a program Rumah Perubahan Rhenald Kasali", is intended to describe the use of speech actin the form of locutionary, illocutionary, perlocutionary acts and the use of expressives to congratulate, thank, criticize, complain, wonder, praise and apologize by speakers to interlocutors in a program Rumah Perubahan Rhenald Kasali. The method used in this research is descriptive qualitative method with observing, recording and taking note techniques. Based on the result of the research, there are 10 speech acts and 11 expressives found in the program, with the speech act consisting of 3 locutionary acts, 2 illocutionary acts and 5 perlocutinary acts and with the expressive including 2 expressions of congratulating, 2 expressions of thanking, 1 expression of criticizing, 1 expression of complaining, 2 expressions of wondering, 2 expressions ofpraising and 1 expression of apologizing.
\end{abstract}

Keywords: speech acts, function of expressives

\section{Pendahuluan}

Pemakaian bahasa dalam berkomunikasi melibatkan beberapa aspek. Aspek-aspek yang dimaksud adalah (1) hal yang dikomunikasikan, (2) tujuan komunikasi, (3) orang yang diajak berkomunikasi, dan (4) tempat komunikasi tersebut berlangsung. Kesanggupan memilih kata seorang penutur dapat menjadi salah satu penentu santun tidaknya bahasa yang digunakan. Pilihan kata yang dimaksud adalah ketepatan pemakaian kata untuk menggunakan makna dan maksud dalam konteks tertentu sehingga menimbulkan efek tertentu pada mitra tutur. Pranowo (2012: 3) menegaskan bahwa pemakaian bahasa secara santun belum banyak mendapat perhatian. Oleh karena itu, wajar kita sering menemukan pemakaian bahasa yang baik ragam bahasanya dan benar tata bahasanya tetapi nilai rasa yang terkandung di dalamnya menyakitkan hati pembaca atau pendengarnya.

Hal ini terjadi karena pemakai bahasa belum mengetahui bahwa di dalam struktur bahasa terdapat struktur kesantunan. Struktur bahasa yang santun adalah struktur bahasa yang disusun oleh penutur atau penulis agar tidak menyinggung perasaan pendengar atau pembaca. Hal inilah yang belum banyak mendapatkan perhatian para ahli bahasa. 
Selanjutnya, struktur bahasa yang santun, faktor-faktor linguistik seperti artikulasi, pitch, variasi keras lembutnya ucapan, kecepatan berbicara, maupun jeda masih menjadi permasalahan yang erat dihadapi penutur saat berbicara. Selain itu, kesantunan nonverbal mengenai gerakan tubuh atau sikap seperti badan membungkuk, pandangan mata tidak melotot, kaki yang terlalu membuka, dagu yang terlalu mendongkak, dan lain sebagainya belum dapat teratasi dengan maksimal.

Penelitian yang dilakukan oleh Andy (2009: 15) berjudul Etika Komunikasi dalam Penyampaian Aspirasi menyoroti tentang etika berkomunikasi tidak hanya berkaitan dengan tutur kata yang baik, tetapi juga harus berangkat dari niat tulus yang diekspresikan dari ketenangan, kesabaran dan empati kita dalam berkomunikasi. Bentuk komunikasi yang demikian akan menghasilkan komunikasi dua arah yang bercirikan penghargaan, perhatian, dan dukungan secara timbal balik dari pihak-pihak yang berkomunikasi. Oleh karena itu, kesantunan verbal dan nonverbal tidak dapat diabaikan atau diunggulkan salah satunya melainkan keduanya harus bersinergi.

Tidak selamanya capaian yang dihasilkan penutur sesuai harapan karena tidak terjadinya komunikasi dua arah sehingga tuturan dianggap gagal. Chaer (2010a: 39) mengemukakan bahwa faktor yang menyebabkan satu proses komunikasi menjadi gagal biasanya datang dari lawan tutur, antara lain (a) lawan tutur tidak mempunyai pengetahuan yang dibicarakan, (b) lawan tutur dalam keadaan "tidak sadar", (c) lawan tutur tidak tertarik dengan topik yang dituturkan, (d) lawan tutur tidak berkenan dengan cara penutur menyampaikan informasi, (e) lawan tutur tidak mempunyai apa yang diinginkan penutur, (f) lawan tutur tidak memahami yang dimaksud penutur, dan $(\mathrm{g})$ lawan tutur tidak mau melanggar kode etik.

Kesadaran bentuk sopan santun menjadi syarat dalam percakapan. Perwujudan sopan santun berbahasa atau etiket berbahasa terlahir dari sikap yang hormat pula. Bentuk lain dari sopan santun adalah pengungkapan suatu hal dengan cara tidak langsung. Salah satu bentuk ketidaklangsungan dapat ditemukan dalam maksud yang tersirat dalam ujaran. Di dalam hal ini, ketidaklangsungan mensyaratkan kemampuan seseorang untuk menangkap maksud yang tersirat, misalnya menanggapi sebuah kalimat yang diujarkan orang lain sebagai sebuah perintah. Maksud yang terkandung di dalam ujaran itu disebut implikatur (Kushartanti, 2009: 106).

Fungsi kesantunan berbahasa terbagi menjadi tiga bentuk, yaitu bentuk deklaratif, bentuk interogatif, dan bentuk imperatif. Bentuk deklaratif berfungsi (a) sikap menghormati mitra tutur dengan mengucapkan salam, (b) menyapa dengan senyuman ataupun anggukan kepala sebagai pendukung kesantunan berbahasa, dan (c) menunjukkan sikap menghormati orang ketiga dengan penanda gaya bahasa sebagai sikap rendah hati dan memuji mitra tutur. Bentuk interogatif memiliki fungsi (a) peduli terhadap mitra tutur, (b) permintaan pengakuan dengan penanda kata tanya berpartikel-kah, (c) meminta keterangan, (d) meminta pendapat, dan (e) menunjukkan kepercayaan terhadap mitra tutur. Bentuk imperatif mempunyai fungsi (a) pemberian ucapan selamat, (b) memohon atau meminta, dan (c) meminta maaf.

Salah satu bentuk komuniksasi tidak langsung adalah melalui televisi. Di dalam tayangan televisi ditemukan tuturan-tuturan yang disampaikan dengan cara langsung maupun tidak langsung. Cara langsung, penonton dengan cepat memahami maksud yang ingin disampaikan, tetapi berbeda apabila penyampaian yang tidak langsung karena menimbulkan makna ganda karena latar belakang penonton yang berbeda-beda. Salah satu acara televisi adalah Rumah Perubahan Rhenald Kasali yang ditayangkan di TVRI. TVRI merupakan stasiun televisi yang masih memperhatikan nilai-nilai pendidikan disetiap tayanganya bukan hanya sekedar mengejar ranking tayang. 
Rhenald Kasali tak hanya dikenal sebagai dosen terbaik Fakultas Ekonomi UI, ia juga aktif menulis dan mengisi berbagai acara seminar. Tahun 2012, sudah ada 14 judul buku yang diterbitkan dan tahun 2007 mendirikan Yayasan Rumah Perubahan yang bertujuan untuk menjadikan Indonesia lebih baik melalui misi perubahan. Acara Rumah Perubahan dipandu oleh Intan Erlita yang memulai karier sebagai presenter pada tahun 2000. Tentu latar belakang pendidikan dan pekerjaan Rhenald Kasali dan Intan Erlita membiasakan diri untuk bertutur dan bersikap santun. Oleh sebab itu, permasalahan yang dibahas dalam penelitian ini adalah (1) bagaimanakah jenis-jenis tindak tutur yang terdapat pada acara Rumah Perubahan Rhenald Kasali?, dan (2) bagaimanakah bentuk dan fungsi tuturan ekspresif yang terdapat pada acara Rumah Perubahan Rhenald Kasali?

Selanjutnya, tujuan dalam penelitian ini adalah untuk mengetahui dan mendiskripsikan (1) jenis-jenis tindak tutur yang terdapat pada acara Rumah Perubahan Rhenald Kasali?, dan (2) bentuk dan fungsi tuturan ekspresif yang terdapat pada acara Rumah Perubahan Rhenald Kasali. Manfaat yang diharapkan dalam penelitian ini adalah secara praktis dapat menumbuhkan kesadaran bahwa acara di televisi bukan hanya disaksikan dan dinikmati saja, tetapi juga memanfaatkannya untuk kritis mengenai tujuan acara dan kesantunan verbal maupun nonverbal yang melingkupinya. Selain itu, secara teoritis penelitian ini dapat menjadi pengembangan ilmu pragmatik dan memberikan sumbangan terhadap pemahaman tindak tutur dan bentuk ekspresif khususnya dalam tayangan di televisi.

\section{Tinjauan Pustaka}

Tindak tutur merupakan gejala individual, bersifat psikologis dan keberlangsungannya ditentukan oleh kemampuan bahasa si penutur dalam menghadapi situasi tertentu.Dalam tindak tutur lebih dilihat pada makna atau arti tindakan dalam tuturannya. Tindakan dalam tuturan akan terlihat dari makna tuturan (Chaer, 2010b: 50). Selanjutnya, Yule (2014a: 82) menambahkan bahwa penutur dan pendengar biasanya terbantu oleh keadaan di sekitar lingkungan tuturan itu. Keadaan semacam ini, termasuk juga tuturan-tutran yang lain disebut peristiwa tutur. Sifat peristiwa tuturlah yang menentukan penafsiran terhadap suatu tuturan ketika menampilkan suatu tindakan tutur khusus. Jenis tindak tutur imperatif terbagi menjadi tiga jenis yaitu (1) locution (lokusi), (2) illocution (ilokusi), dan (3) perlocution (perlokusi).

Tindak tutur locution adalah tuturan yang disampaikan kepada mitra tutur atau tindak tutur yang mengacu ke tindakan mengucapkan tuturan yang secara semantis mempunyai makna. Contoh tuturan locution adalah "Saya sedih". Kalimat tersebut jika disampaikan kepada teman senasib meskipun tidak dijelaskan secara detail, mereka akan menyadari karena rasa sedih tersebut disebabkan oleh studinya yang bertahun-tahun belum lulus. Tindak tutur ilokusi merupakan tuturan apa yang ingin disampaikan kepada mitra tutur atau tindak tutur yang megacu ke tindakan mengucapkan tuturan yang di samping mempunyai makna sematis juga mempunyai dayatuturan atau maksud tuturan (di dalam arti untuk apa tuturan itu diungkapkan). Contoh tindak ilokusi yakni "Jalan berlubang". Kalimat tersebut disampaikan kepada pengendara sepeda montor agar berjalan berhati-hati dan waspada.

Selanjutnya, tindak tutur perlokusi yaitu pesan yang harus diinterprestasikan oleh mitra tutur atau dengan istilah lain bahwa tutur ini mengacu ke tindakan mengucapkan tuturan di samping mempunyai makna (semantis), dan mempunyai daya (yang bertumpu pada maksud tuturan), juga mempunyai efek kepada si mitra tutur. Efek atau daya tuturan itu dapat ditimbulkan oleh penutur secara sengajan atau dapat pula secara tidak sengaja. Contoh tindak perlokusi "Tahun depan masa studimu sudah berakhir". Tuturan ini jika disampaikan jepada mahasiwa yang benar-benar sudah pada tahun akhir tersebut akan memiliki daya pengaruh terhadap mahasiswanya. Hal ini juga berdampak kepada mahasiswa menjadi ketakutan jika dirinya dikenakan sangsi dikeluarkan (drop out) (Austin dalam Sulistyo, 2013a: 6-7). 
Selain etika berbahasa, hal yang tidak luput diperhatikan adalah tuturan ekspresif yang digunakan pemakai bahasa. Yule (2014b: 93) berpendapat bahwa dalam tindak tutur ekspresif terdapat pernyataan yang menggambarkan apa yang penutur rasakan. Tindak tutur ini mencerminkan pernyataan-pernyataan psikologis penutur terhadap suatu keadaan, meliputi mengucapkan terima kasih, terkejut, mengucapkan selamat datang, mengucapkan selamat, gembira, khawatir, sombong dan rasa tidak suka. Tindak tutur ekspresif menilai atau mengevaluasi tindakan sebelumnya atau kegagalan tersebut dari penutur atau mungkin hasil bertindak atau kegagalan tersebut sekarang (Sulistyo, 2013b: 10).

Selanjutnya, Supriyadi (2011: 64) menambahkan tindak tutur ekspresif bersifat retrospeksi dan melibatkan penutur. Verba tindak tutur ekspresif antara lain bersimpati, memaafkan, belasungkawa, ikut prihatin, dan sebagainya. Bentuk tuturan ekspresif di antaranya adalah (1) mengucapkan selamat, (2) terima kasih, (3) mengkritik, (4) mengeluh, (5) heran, (6) memuji, dan (7) meminta maaf.

Pertama, tuturan ekspresif ucapan selamat merupakan tindak tutur yang terjadi karena beberapa faktor, yakni penutur mendapatkan sesuatu yang istimewa, penutur memberikan sambutan istimewa kepada lawan tutur, atau sebagai sambutan atau salam penanda waktu sehingga lawan tuturnya mengucapkan selamat kepada penutur sebagai ekspresi kebahagiaan. Kedua, tuturan ekspresif ucapan terima kasih merupakan tindak tutur yang biasanya terjadi karena beberapa faktor diantaranya yaitu dikarenakan mitra tutur atau lawan tuturnya bersedia melakukan apa yang diminta oleh penutur dikarenakan tuturan 'memuji' yang dituturkan oleh penutur kepada lawan tutur, atau dikarenakan kebaikan hati penutur yang telah memberikan sesuatu kepada lawan tutur.

Ketiga, tuturan ekspresif mengkritik merupakan tindak tutur yang terjadi karena penutur merasa tidak suka atau tidak sependapat dengan apa yang dilakukan atau dituturkan oleh lawan tuturnya. Tuturan mengkritik biasanya berupa tanggapan, kadang-kadang disertai dengan uraian dan pertimbangan baik buruk terhadap suatu hasil karya, pendapat, dan lain sebagainya. Keempat, tuturan ekspresif mengeluh merupakan tindak tutur yang terjadi karena ingin mengungkapkan rasa susah yang disebabkan oleh penderitaan, kesakitan, ataupun kekecewaan. Kelima, tuturan ekspresi heran merupakan tindak tutur yang disebabkan merasa sesuatu kejadian yang dilihat dan dialami oleh orang lain dianggap tidak wajar bagi dirinya maupun menyimpang dari suatu budaya pada suatu masyarakat.

Keenam, tuturan ekspresif menyanjung atau memuji merupakan tindak tutur yang terjadi karena beberapa faktor, yakni dikarenakan kondisi dari lawan tutur yang sesuai dengan kenyataan yang ada karena penutur ingin melegakan hati lawan tutur karena penutur ingin merayu lawan tutur, karena penutur ingin menyenangkan hati lawan tutur atau karena perbuatan terpuji yang dilakukan oleh penutur. Ketujuh, tuturan ekspresif meminta maaf merupakan tindak tutur yang terjadi karena perasaan tidak enak penutur terhadap lawan tutur karena telah menganggu waktu lawan tutur atau karena telah melakukan kesalahan (Sari, 2012: 7-10).

\section{Metodologi Penelitian}

Sumber data penelitian ini diambil dari episode "Guru, Ayolah Berubah!" yang tayang pada tanggal 2 Juli 2013 terdiri dari enam bagian, yaitu bagian pertama "pembuka", bagian kedua "Guru Gokil Murid Unyu", bagian ketiga "Mengabdi dan Melayani Murid", bagian keempat "Belajar dari Live In", bagian kelima "Baca Jadi Tradisi Guru", dan bagian keenam "Simpulan". Acara ini tayang pada setiap hari Selasa pukul 20.00 WIB di TVRI. Setelah peneliti mencari video episode tersebut pada website acara Rumah Perubahan Rhenald Kasali maupun youtube kemudian mengunduh serta melakukan transkip hingga bagian terakhir 
Metode penelitian yang digunakan dalam penelitian ini adalah metode kualitatif deskriptif. Hal ini disebabkan data-data dalam penelitian ini berupa mendeskripsikan, menganalisis, dan menginterprestasikan tuturan-tuturan antara penutur dan lawan tutur. Data yang telah dikumpulkan selanjutnya akan disajikan dalam bentuk uraian-uraian kualitatif tentang tindak tutur lokusi, ilokusi, perlokusi, dan fungsi tuturan ekspresifnya dengan memperhatikan data yang ada.

\section{Hasil dan Pembahasan}

Pada bagian pembahasan, peneliti akan memaparkan mengenai tindak tutur dan tuturan ekspresif pada acara Rumah Perubahan Rhenald Kasali episode "Guru, Ayo Berubahlah!" sebagai berikut.

\section{Tindak Tutur Acara Rumah Perubahan Rhenald Kasali}

Tindak tutur acara Rumah Perubahan Rhenald Kasali terbagi menjadi tiga jenis, yaitu tindak tutur lokusi, tindak tutur ilokuis, dan tindak tutur perlokusi.

\section{Tindak Tutur Lokusi}

Berikut ini penggunaan tindak tutur lokusi pada acara Rumah Perubahan Rhenald Kasali.

Data 1 Bagian 1 "Pembuka"

\section{Konteks}

Intan Erlita menyampaikan pendapatnya kepada Rhenald Kasali mengenai siswa yang terlihat memperhatikan guru tetapi pikiran di luar kelas dikarenakan cara mengajar guru yang monoton.

\section{Intan Erlita}

Guru Berubahlah! Kadang-kadang kalau kita lihat kalau menjadi seorang siswa kalau kita mempunyai guru yang hanya memberikan materi, kita kadang duduknya rapi ya.. sikapnya sempurna, tetapi badan ada disitu pikiran gini 'kapan ya selesainya, kayaknya makan di kantin enak' hee... pikirannya makanan ya (tersenyum), tapi emang seperti itu Pak Rhenald, kalau kita hanya menerima satu arah saja kan?

\section{Rhenald Kasali}

Cara mengajar harus berubah karena sekarang semua orang adalah hidup dalam peradapan interaktif. Peradapan interaktif semua orang bisa berinteraksi, jangankan kepada guru, kepada penyiar TV, kepada orang terkenal aja, Anda semua saja punya akses saat ini ya.. Punya akses, bisa ngetwett, dibalas pula, ya.. masa jadi guru tidak mau membalas, gak mau jawab.

Pada data 1 bagian 1 "Pembuka" di atas terdapat percakapan yang berupa tindak tutur lokusi antara Rhenald Kasali (penutur) dan pembawa acara Intan Erlita (lawan tutur). Tuturan "Cara mengajar harus berubah karena sekarang semua orang adalah hidup dalam peradapan interaktif. Peradapan interaktif semua orang bisa berinteraksi, jangankan kepada guru, kepada penyiar TV, kepada orang terkenal aja, Anda semua saja punya akses saat ini ya.. Punya akses, bisa ngetwett, dibalas pula, ya.. masa jadi guru tidak mau membalas, gak mau jawab" disampaikan oleh Rhenald Kasali kepada Intan Erlita yang hanya bersifat informatif saja tanpa adanya tendensi tertentu untuk melakukan sesuatu apalagi untuk mempengaruhi lawan tuturnya. Tuturan tersebut diutarakan untuk memberitahukan bahwa penutur ingin memberikan pendapatnya tentang cara mengajar guru yang harus berubah seiring kemajuan zaman.

\section{Tindak Tutur Ilokusi}

Penggunaan tindak tutur ilokusi pada acara Rumah Perubahan Rhenald Kasali adalah sebagai berikut.

Data 2 Bagian 2 “Guru Gokil Murid Unyu” 


\section{Konteks}

Intan Erlita menyampaikan pendapatnya kepada Rhenald kasali, salah satu siswa giat belajar adalah salah satu faktor merasa dekat dengan guru.

\section{Intan Erlita}

Nah itu dia suatu quate yang luar biasa kan. Kalau kita sekarang belajar, kita hanya mendengarkan cuma akan lewat saja tapi pak Rhenald mungkin sedikit guru yang mau mengubah konsep artinya mau mendekatkan diri pada murid-murid mungkin cara belajarnya diubah mungkin sebenarnya tanpa disadari membuat murid giat belajar.

\section{Rhenald kasali}

Ya betul, jadi tentu saja tergantung siapa gurunya ya. Kalau gurunya yang menakuti, guru yang menyeramkan, tentunya tidak akan efektif. Guru haruslah yang friendly, harus bersahabat, jadi jangan sampai anda cita-cita menjadi guru dan mukannya dibikin yang seram ya, mukanya dibikin serem, terlalu banyak apa wajahnya penuh dengan simbol, pakainnya simbol. Anda ingin jadi apa ya gaya peraga busana atau yang serem-serem terus kata-katanya juga, keluarlah kebun binatang. Itu bukan guru. Guru yang baik adalah guru yang memberi contoh dan harus bersahabat sehingga murid-murid tidak merasa terancam.

Data 2 bagian 2 "Guru Guru Murid Unyu" di atas terdapat percakapan yang berupa tindak tutur ilokusi antara lawan tutur dengan penutur dengan tuturan "Kalau kita sekarang belajar, kita hanya mendengarkan cuma akan lewat saja tapi pak Rhenald mungkin sedikit guru yang mau mengubah konsep artinya mau mendekatkan diri pada muridmurid mungkin cara belajarnya dirubah mungkin sebenarnya tanpa disadari membuat murid giat belajar". Disampaikan oleh lawan tutur bahwa bila guru mau mengubah cara penyampaian materi dengan pendekatan dapat berakibat siswa akan mengalami perubahan sikap yaitu rajin belajar.

Pernyataan pembawa acara disetujui oleh penutur dengan tuturan "Guru yang baik adalah guru yang memberi contoh dan harus bersahabat sehingga murid-murid tidak merasa terancam". Tuturan tersebut bermakna sebagian guru hanya berambisi bahwa siswa harus bisa menerima semua materi yang disampaikan dan berprestasi secara nilai yang tidak membuat guru kecewa, tetapi hal yang terlupakan oleh guru-guru adalah cara penyampaian materi tersebut. Guru mengganggap selalu paling benar tanpa mengevalusi keputusankeputusan yang diambil baik sebelum, selama, dan sesudah pembelajaran. Apabila siswa telah merasa dekat dengan gurunya secara tidak langsung reaksi rasa suka terhadap mata pelajaran akan timbul.

\section{Tindak Tutur Perlokusi}

Di bawah ini dipaparkan penggunaan tindak tutur perlokusi pada acara Rumah Perubahan Rhenald Kasali.

\section{Data 3 Part 3 "Guru Gokil Murid Unyu"}

\section{Konteks}

Rhenald Kasali mengajukan pertanyaan kepada Sumardianta mengenai sikapnya yang berpenghasilan cukup tetapi masih ingin berbagi buku kepada siswanya.

\section{Rhenald Kasali}

Ketika sebagian besar guru yang lain mengeluh mengenai tentang uang, Anda membagibagikan buku. Apa Anda gak salah?

\section{Sumardianta}

Begini, justru pada saat saya berbagi justru banyak kejutan-kejutan lain. Ada-ada saja. Ada-ada saja kejutan, rezeki yang diluar dugaan saya. Jadi prinsip saya itu bukan membuat murid menjadi cerdas, bukan sekedar menjadi cerdas juga terampil. Tugas saya adalah delivery happienes. 
Data 3 terdapat tuturan "Jadi prinsip saya itu bukan membuat murid menjadi cerdas, bukan sekedar menjadi cerdas juga terampil. Tugas saya adalah delivery happienes". Efek atau daya pengaruh yang disampaikan adalah mempengaruhi lawan tutur bahwa tugas guru bukan hanya menyampaikan materi yang membuat siswanya menjadi cerdas. Keterampilan juga diperlukan oleh siswa dengan menimbulkan rasa bahagia baik dari guru dan juga siswa. Salah satu contoh yang dilakukan oleh penutur adalah dengan membagibagikan buku bacaan kepada siswa.

\title{
Data 4 Part 6 "Simpulan"
}

Konteks

Rhenald Kasali meminta Sumardianta menyampaikan pesan yang ingin disampaikan kepada guru.

\section{Rhenald Kasali}

Kita tidak bisa mengatakan, guru adalah pembuat masalah tapi kehidupan memang seperti ini. Tentu kita harus berempati di dalam kesulitan-kesulitan para guru. Pesan apa yang bisa anda katakan pada mereka?

\section{Sumardianta}

Guru itu adalah manusia dan sebagai manusia jangan mentok jangan pasrah menghadapi masalah. Kalau kita fokusnya, pusat perhatiannya kita ke murid, kejutan-kejutan, persoalan ekonomi, persoalan macam-macam itu menurut pengalaman saya akan selesai dengan sendirinya, tetapi semakin kita bingung dengan penghasilan kita yang kecil semakin kita masuk ke kelas bertemu dengan guru, bertemu dengan kawan itu bau remason, masuk angin karena stres, dan saya gak mau itu.

Data 4 terdapat tuturan "Guru itu adalah manusia dan sebagai manusia jangan mentok jangan pasrah menghadapi masalah" yang disampaikan penutur dengan tujuan memberikan daya pengaruh tertentu terhadap lawan tuturnya. Daya pengaruh yang disampaikan penutur melalui tuturan tersebut adalah mempengaruhi lawan tutur bahwa guru bukan malaikat, guru adalah manusia yang tak luput dari kesalahan. Penutur menyampaikan asumsinya bahwa meskipun penghasilan guru kecil, jangan terlalu memikirkan penghasilan tersebut, apabila dijalani dan kita melaksanakan kewajiban kita yaitu mengabdi dan melayani murid permasalahan-permasalah yang dihadapi seperti permasalahan ekonomi tanpa disadari akan dapat terselesaikan dengan sendirinya. Maha Pencipta akan selalu mempermudah dan memberikan jalan keluar di setiap permasalahan apalagi kepada orang-orang yang menyampaikan ilmu.

\section{Fungsi Tuturan Ekspresif}

Fungsi tuturan ekspresi dalam acara Rumah Perubahan Rhenald Kasali terkandung tuturan dalam sebuah ujaran yang disampaikan oleh penutur kepada lawan tuturnya, yakni berfungsi untuk mengucapkan selamat, terima kasih, mengkritik, mengeluh, heran, memuji, dan meminta maaf.

\section{Tuturan Ekspresif Ucapan Selamat}

Penggunaan tuturan ucapan selamat mengeluh pada acara Rumah Perubahan Rhenald Kasali sebagai berikut.

\author{
Data 5 Part 1 "Pembukaan" \\ Konteks \\ Intan Erlita membuka acara dan menyapa penonton. \\ Intan Erlita \\ Ya...Halo permirsa, apa kabar senang sekali saya Intan Erlita dan juga \\ Rhenald Kasali \\ Saya Rhenald Kasali selamat malam
}


Frasa pada data 5 "apa kabar dan selamat malam" memiliki kesantunan tuturan berbahasa berbentuk deklaratif dan imperasif yang didukung aspek kinesik berupa senyuman disertai dengan anggukan kepala. Kegiatan memberi salam sangat dianjurkan karena secara tidak langsung membuat mitra tutur merasa senang dan mencerminkan rasa hormat terhadap mitra tutur.

\section{Tuturan Ekspresif Ucapan Terima Kasih}

Penggunaan tuturan ucapan terima kasih pada acara Rumah Perubahan Rhenald Kasali sebagai berikut.

\section{Data 6 Part 2 "Guru Gokil Murid Unyu"}

Konteks

Rhenald Kasali menyampaikan terima kasih kepada narasumber karena bersedia hadir memenuhi undangan

\section{Rhenald Kasali}

Selamat malam, bapak guru gokil. Terima kasih kedatangannya.

\section{Sumardianta}

Selamat malam pak Rhenald.

Data 6 terdapat tuturan "terima kasih" karena narasumber guru gokil bersedia datang dari Jogja ke Jakarta. Rasa senang penutur ditunjukan dengan kesantunan menyambut lawan tutur dengan berjabat tangan sembari tersenyum.

\section{Tuturan Ekspresif Mengkritik}

Penggunaan tuturan ekspresif mengkritik pada acara Rumah Perubahan Rhenald Kasali sebagai berikut.

\section{Data 7 Part 4 "Belajar dari Live In" \\ Konteks}

Rhenald Kasali mengajukan pertanyaaan kepada Sumardianta mengenai ajakan kepada guru untuk melakukan perubahan.

\section{Rhenald Kasali}

Baik. Ya itu salah satu ilmu hidup ya. Life skill. Life skill. Kalau kita katakan kalau kita mengajak guru untuk berubah apa yang anda harapkan dari perubahan itu?

\section{Sumardianta}

Perilaku guru yang sekarang ya misalnya guru yang sepanjang hari, sepanjang minggu, sepanjang hidupnya ceramah di kelas. Menurut saya, perilakunya adalah akibat dari cara berpikirnya. Jadi perilaku itu sebenarnya ada sebabnya. Sebabnya diparadigma para gurunya karena menurut saya yang harus diubah adalah paradigmanya pak.

Data 7 terdapat percakapan yang berupa tuturan ekspresif mengkritik "Sebabnya diparadigma para gurunya karena menurut saya yang harus dirubah adalah paradigmanya pak" disampaikan oleh penutur dengan maksud mengkritik model pembelajaran guru yang tidak inovatif. Model pembelajaran ceramah dianggap paling manjur. Penutur ingin mengajak para guru merubah cara pikir, tuntutan kemajuan zaman membuat guru harus menjadi guru modern dalam arti sumber belajar, gaya penyampaian materi, dan pendukung proses pembelajaran lainnya harus disesuaikan.

\section{Tuturan Ekspresif Mengeluh}

Penggunaan tuturan ekspresif mengeluh pada acara Rumah Perubahan Rhenald Kasali sebagai berikut.

\section{Data 8 Part 3 "Mengabdi dan Melayani Murid" \\ Konteks}

Rhenald Kasali mengajukan pertanyaan kepada narasumber tentang kebiasaannya membagi buku dengan penghasilan yang hanya dikatakan cukup. 


\author{
Rhenald Kasali \\ Cukup uang Anda untuk bagi-bagikan? \\ Sumardianta \\ Kadang-kadang, kalau gak ya terpaksa saya suruh mereka foto copy. \\ Rhenald Kasali \\ Foto copy, kasihan dong? \\ Sumardianta \\ Terpaksa Pak Rhenald \\ Rhenald Kasali \\ Terpaksa ya \\ Sumardianta \\ Demi mencerdaskan kehidupan bangsa
}

Pada data 8 terdapat percakapan yang berupa tuturan ekspresif mengeluh "Cukup uang Anda untuk bagi-bagikan?", dijawab oleh penutur dengan tuturan "Kadang-kadang, kalau gak ya terpaksa saya suruh mereka foto copy". Jawaban penutur bermaksud menceritakan keluhan penutur dengan gaji yang ia terima dengan jumlah yang dikatakan cukup harus ia bagi untuk kebutuhan keluarga dan sikapnya yang suka bagi-bagi buku. Ia mengalami kesulitan saat ia tidak bisa membagikan buku dan meminta siswa untuk memfotocopy dikarenakan terkendala dana dengan ekspresi berubah mengkerutkan wajah dengan mata yang menahan air mata. Frasa "terpaksa" pada di atas menunjukan pesan tersirat tekanan batin penutur yang dirasakan antara keinginan dan kenyataan yang tidak sama. Pernyataan data sikap terpaksa ditunjukkan dengan tuturan "Demi mencerdaskan kehidupan bangsa" yang semakin menunjukkan bahwa pendidikan bukan hanya tanggung jawab pendidik, tetapi seluruh lapisan, pemerintah, orang tua, dan masyarakat. Saat menjawab dengan tuturan tersebut ekspresi penutur berubah tegas dan menampilkan wajah penuh semangat.

\title{
5. Tuturan Ekspresif Heran
}

Berikut ini tuturan ekspresif heran dalam acara Rumah Perubahan Rhenald Kasali.

Data 9 Part 2 "Guru Gokil Murid Unyu"

Konteks

Intan Erlita menceritakan pengalamannya kepada Rhenald Kasali dan penonton.

\section{Intan Erlita}

Nah tapi itu sekarang sudah mulai pak Rhenald. Saya pernah melihat di satu pusat pembelajaan dan satu anak dijagain dua baby sister pak.

\section{Rhenald Kasali}

Ya satu anak dua baby sister, ya ya ya.

Intan Erlita

Saya bingung, itu apa saja tugasnya ya, jobnya?

Data 9 di atas, lawan tutur menyatakan keherannya kepada penutur saat melihat satu anak yang dijaga oleh dua baby sister. Padahal satu baby sister pun sudah mampu untuk menjaga satu orang anak. Tentu apabila dipandang dari ekonomi, orang tua yang memperkerjakan dua baby sister untuk menjaga satu anaknya pasti secara ekonomi tergolong orang tua yang mapan dan berlebihan, tetapi hal ini banyak kita jumpai terutama di kota-kota besar. Tuturan keheranan penutur juga dipertegas dengan ujaran "Saya bingung, itu apa saja tugasnya ya, jobnya?". Lawan tutur hanya menjawab keheranan penuntur dengan tuturan "ya" yang diulang sebanyak tiga kali, menandakan persetujuan pernah melihat hal tersebut.

\section{Tuturan Ekspresif Memuji}

Penggunaan tuturan ekspresif memuji dalama acara Rumah Perubahan Rhenal Kasali adalah sebagai berikut. 


\section{Data 10 Part 4 "Belajar dari Live In" \\ Konteks}

Sumardianta mempertegas mengenai pertanyaan yang diajukan Rhenald Kasali

Sumardianta

Oh tidak. Maksudnya saya ingin menggambarkan kota yang terisolasi.

\section{Rhenald Kasali}

Kota yang terisolasi yang jam 7 saja sudah sepi kota itu. Baik. Kemudian dari pengalaman Anda, Anda membentuk manusia-manusia seperti ini ya, tentu saja ini tidak mudah, apalagi ada orang tua yang bilang ini pendidikan apa ini, adakah yang seperti itu?

Pada data 10 di atas terdapat tuturan ekspresif yang berupa tuturan ekspresif memuji. Tuturan "Kemudian dari pengalaman Anda, Anda membentuk manusia-manusia seperti ini ya, tentu saja ini tidak mudah, apalagi ada orang tua yang bilang ini pendidikan apa ini, adakah yang seperti itu?" bermaksud sikap pujian yang ingin disampaikan penutur kepada lawan tutur dengan penegasan intionasi yang diperlambat serta memandang dan posisi sedikit didekatkan dengan lawan tutur menunjukkan rasa empati "Anda membentuk manusia-manusia seperti ini ya, tentu saja ini tidak mudah".

Gebrakan model pembelajaran yang dibuat guru gokil Pak Sumardianta mengajak muridmuridnya selama seminggu ke lokasi-lokasi yang tidak pernah ditemui mereka mengalami berbagai kendala terutama memberikan pengertian kepada orang tuan murid, tetapi perlahan kegiatan ini mendapat dukungan penuh bukan hanya dari orang tua dan pihak sekolah tetapi siswa mendapatkan pengalaman hidup setelah proses pembelajaraan tersebut.

\section{Data 11 Part 4 "Belajar dari Live In" \\ Konteks}

Penonton bertanya setelah dipersilahkan oleh pembawa acara

Penonton

Selamat malam pak Sumar. Begini pak, ada beberapa guru atau dosen seperti Prof Rhenald Kasali itu kalau mengajar dengan beberapa guru itu yang asik. Guru asik atau guru gokil kalau lagi nerangin muridnya sampai mengangguk-angguk "wah bagus nih" sementara ada beberapa guru yang saat nerangin, muridnya mengangguk-angguk tapi matanya ngantuk nih pak. Pertanyannya gimana sih pak cara menyampaikan materi secara gokil agar muridmurid jadi unyu pak. Terima kasih.

Data 11 di atas terdapat tuturan yang disampaikan oleh penonton saat mengajukan pertanyaan "Begini pak, ada beberapa guru atau dosen seperti Prof Rhenald Kasali itu kalau mengajar dengan beberapa guru itu yang asik". Tuturan tersebut menunjukkan ekspresif pujian penonton kepada lawan tuturnya di hadapan langsung sebagai contoh guru yang dianggap dia termasuk guru asik. Tentu penyampaian pujian secara langsung ini membuat lawan tuturnya merasa senang terlihat dengan respon Rhenal Kasali dengan tersenyum dan tertawa kecil.

\section{Tuturan Ekspresif Meminta Maaf}

Tuturan ekspresi meminta maaf pada acara Rumah Perubahan adalah sebagai berikut.

\section{Data 12 Part 3 "Mengabdi dan Melayani Murid"}

\section{Konteks}

Rhenald Kasali mengajukan pertanyaan kepada Sumardianta mengenai gebrakan yang dilakukan dengan emercy program.

\section{Rhenald Kasali}

Itu adalah masalah hidup

Sumardianta 
Masalah hidup dan pendidikan seterusnya menyentuh itu, baru pelajaran mengikuti. Tapi kalau guru, sekolah tidak sabar ingin segera mencekoki, memindahkan materi ke otak mereka, mohon maaf ini .... sama saja menjadikan otak siswa itu sebagai keranjang sampah. Ada masalah dengan. Ada masalah dengan korupsi, mau bikin kurikulum anti korupsi. Ada permasalahan dengan lingkungan, kita ingin memasukan kurikulum tentang lingkungan hidup.

Pada data 12 di atas, terdapat tuturan "Tapi kalau guru, sekolah tidak sabar ingin segera mencekoki, memindahkan materi ke otak mereka, mohon maaf ini .... sama saja menjadikan otak siswa itu sebagai keranjang sampah", tuturan yang disampaikan oleh penutur kepada lawan tutur. Maksud dari tuturan tersebut adalah penutur meminta maaf kepada lawan tutur karena merasa tidak enak sebab pada tuturan tersebut ada guru yang merasa seperti yang dikatakan penutur. Hal ini tampak saat penutur saat mengibaratkan otak siswa yang seperti keranjang sampah dengan permohonan maaf sebelumnya "mohon maaf ini” dengan sedikit jeda sebelum melanjutkan tuturannya.

\section{Simpulan dan Saran \\ Simpulan}

Berdasarkan hasil analisis di atas, dapat disimpulkan bahwa dalam acara Rumah Perubahan Rhenal Kasali episode "Guru, Ayo Berubahlah!” di TVRI ditemukan 10 tuturan dan tindak tutur ekspresif ditemukan 11 tuturan. Tuturan tersebut terdiri dari 3 tuturan lokusi, 2 tuturan ilokusi, 5 tuturan perlokusi, 2 tuturan ekspresif ucapan selamat, 2 tuturan ekspresif ucapan terima kasih, 1 tuturan ekspresif mengkritik, 1 tuturan ekspresif mengeluh, 2 tuturan ekspresif heran, 2 tuturan ekspresif memuji, dan 1 tuturan ekspresif meminta maaf.

\section{Saran}

Selanjutnya, televisi sebagai media komunikasi tidak langsung diharapkan dapat menjadi media yang mengapliksaikan kesantunan verbal maupun nonverbal disebabkan tayangan acara televisi memiliki acara yang kini tidak dapat dibatasi siapa yang menyaksikan mulai dari usia anak-anak hingga dewasa. Selain itu, penayangan 24 jam non stop menunjukkan media televisi memiliki daya pengaruh tinggi bagi pemirsa untuk meniru, memakai, mengetahui maupun berpihak pada suatu tayangan.

\section{Daftar Pustaka}

Andy, Corry W. (2009). Etika Berkomunikasi dalam Penyampaian Aspirasi. Jurnal Komunikasi, Vol. 1 No. 1 Tahun 2009. 14-18.

Chaer, Abdul. (2010). Kesantunan Berbahasa. Jakarta: Rineka Cipta.

Kushartanti. (2009). Pesona Bahasa Langkah Awal Memahami Sosiolingusitik. Jakarta: Gramedia.

Pranowo. (2012). Berbahasa secara Santun. Yogyakarta: Pustaka Pelajar.

Sari, Fenda Dina P. (2012). Tindak Tutur dan Fungsi Tuturan Ekspresif dalam Acara Galau Nite di Metro TV: Suatu Kajian Pragmatik. Jurnal Skriptorium, Vol. 1 No. 2 Tahun 2012. 1-14.

Sulistyo, Edy Tri. (2013). Pragmatik: Suatu Kajian Awal. Surakarta: UNS Press.

Supriyadi, Slamet. (2011). Wacana Karikatur Indonesia Perspektif Kajian Pragmatik. Surakarta: UNS Press.

Yule, George. (2014). Pragmatik. Jakarta: Pustaka Pelajar. 